\title{
Designing 3D Membrane Modules for Gas Separation Based on Hollow Fibers from Poly(4-methyl-1-pentene)
}

\author{
Svetlana Yu. Markova ${ }^{1, *}$, Anton V. Dukhov ${ }^{1}\left({ }^{1}\right.$, Martin Pelzer $^{2}$, Maxim G. Shalygin ${ }^{1}{ }^{(}$, Thomas Vad $^{2}$, \\ Thomas Gries $^{2}$ a and Vladimir V. Teplyakov ${ }^{1}$
}

1 A.V. Topchiev Institute of Petrochemical Synthesis RAS, 29 Leninskiy Prospect, 119991 Moscow, Russia; anton.duhov.97@mail.ru (A.V.D.); mshalygin@ips.ac.ru (M.G.S.); tepl@ips.ac.ru (V.V.T.)

2 Institut für Textiltechnik of RWTH Aachen University, Otto-Blumenthal-Straße 1, 52074 Aachen, Germany; Martin.Pelzer@ita.rwth-aachen.de (M.P.); Thomas.Vad@ita.rwth-aachen.de (T.V.);

Thomas.Gries@ita.rwth-aachen.de (T.G.)

* Correspondence: markova@ips.ac.ru; Tel.: +7-(495)-647-59-27 (ext. 229)

check for

updates

Citation: Markova, S.Y.; Dukhov,

A.V.; Pelzer, M.; Shalygin, M.G.; Vad,

T.; Gries, T.; Teplyakov, V.V.

Designing 3D Membrane Modules

for Gas Separation Based on Hollow

Fibers from Poly(4-methyl-1-

pentene). Membranes 2022, 12, 36

https://doi.org/10.3390/

membranes12010036

Academic Editor: Shing-Yi Suen

Received: 11 November 2021

Accepted: 25 December 2021

Published: 27 December 2021

Publisher's Note: MDPI stays neutral with regard to jurisdictional claims in published maps and institutional affiliations.

Copyright: (C) 2021 by the authors. Licensee MDPI, Basel, Switzerland. This article is an open access article distributed under the terms and conditions of the Creative Commons Attribution (CC BY) license (https:// creativecommons.org/licenses/by/ $4.0 /)$.

\begin{abstract}
Designing hollow fiber (HF) membrane modules occupies one of the key positions in the development of efficient membrane processes for various purposes. In developing HF membrane modules, it is very important to have a uniform HF distribution and flow mixing in the shell side to significantly improve mass transfer and efficiency. This work suggests the application of different textile 3D HF structures (braided hoses and woven tape fabrics). The 3D structures consist of meltspun, dense HFs based on poly(4-methyl-1-pentene) (PMP). Since the textile processing of HFs can damage the wall of the fiber or close the fiber bore, the membrane properties of the obtained structures are tested with a $\mathrm{CO}_{2} / \mathrm{CH}_{4}$ mixture in the temperature range of 0 to $40{ }^{\circ} \mathrm{C}$. It is shown that HFs within the textile structure keep the same transport and separation characteristics compared to initial HFs. The mechanical properties of the PMP-based HFs allow their use in typical textile processes for the production of various membrane structures, even at a larger scale. PMP-based membranes can find application in separation processes, where other polymeric membranes are not stable. For example, they can be used for the separation of hydrocarbons or gas mixtures with volatile organic compounds.
\end{abstract}

Keywords: gas separation membrane; poly(4-methyl-1-pentene); hollow fibers; 3D braided hollow fiber membrane structures

\section{Introduction}

The development and practical application of membrane processes have stimulated active research on membrane materials and methods for forming membranes and designing membrane modules. Over the past several years, the interest in hollow fiber (HF) membrane modules has constantly increased. Their main advantages include the following: they have high packing densities and specific productivity, and wide areas of application both in gaseous and liquid media [1]. Advances in membrane material science, the features of selective gas transfer in polymer membranes and the modeling of membrane processes and foundation are systematically and thoroughly presented in the literature [2-6]. The HFs proposed by J. Hennis and M. Tripody [7] focus on gas separation. Nowadays, HFs are used for liquid purification, including pervaporation, membrane distillation, various types of osmosis, gas/liquid and liquid/liquid membrane contactors. Ecologically non-friendly phase inversion methods are mainly used for the production of polymer HFs $[4,7,8]$ and flat-sheet membranes $[9,10]$. Recently, increasing attention has been paid to the environmental problems connected with such production, such as the disposal of solvents and the residue of solvents in the fibers after production. Therefore, production processes for HFs using environmentally friendly methods are being developed. The latest achievements in the production of polymeric HF membranes from an environmental and 
health point of view include the melt/solution integrated homogeneous reinforcement method, the melt spinning-stretching interfacial phase separation method or the utilization of "green" solvents [11].

Unlike most polymer membranes produced with organic solvents, membranes based on poly(4-methyl-1-pentene) (PMP) can be obtained by the melt spinning method without using organic solvents [12]. Thermoplastic PMP is a semicrystalline aliphatic polyolefin, with a glass transition temperature $\mathrm{T}_{\mathrm{g}}$ of $20-30{ }^{\circ} \mathrm{C}$ and a melting temperature $\mathrm{T}_{\mathrm{m}}$ of $230{ }^{\circ} \mathrm{C}$. It has the lowest density compared to all other thermoplastic materials $\left(0.83 \mathrm{~g} / \mathrm{cm}^{3}\right)$ [13]. PMP has high gas permeability coefficients compared to commercial membrane polymers such as polysulfones, polycarbonates, polyimides and their functional derivatives. Other important advantages of PMP include the following: it can be used in industrial production, can form membranes by melt spinning technology, is stable in the presence of $C_{3+}$ hydrocarbons and vapors of organic solvents and has high chemical resistance [14]. These advantages allow it to be considered a promising material for the production of membranes, particularly for gas separation processes, regardless of the moderate level of selectivity. For example, PMP-based membranes have been investigated for gas separation in several studies [15-18].

A technological process used for preparing PMP-based "Graviton" HFs was developed in the 1980s [19]. Unfortunately, in applying membrane modules based on "Graviton" HFs in real gas separation processes, it was discovered that the HFs were blocked due to the capillary condensation of water vapors inside the fiber as a result of its small internal diameter. Today, membranes based on PMP are mainly used for extracorporeal membrane oxygenation ("artificial lungs") [20-22]. PMP has high resistance towards organic components and thus is promising for the separation of hydrocarbons and complex gaseous media with volatile organic compounds (VOCs).

While the formation of various HFs using conventional production processes can be considered sufficiently advanced, membrane modules based on HFs are being actively improved. Table 1 presents the main trends in improving the design of HF membrane modules.

Table 1. Main trends in improving the efficiency of HF membrane modules.

\begin{tabular}{|c|c|c|c|c|}
\hline $\begin{array}{c}\text { Purpose of the } \\
\text { Membrane Module }\end{array}$ & Improvement Area & Improvement Method & Remark & Ref. \\
\hline Gas separation & $\begin{array}{l}\text { Increasing the packing } \\
\text { density }\end{array}$ & $\begin{array}{c}\text { Modeling } \\
\text { (know-how-based technique) } \\
\text { on lab-scale HF membrane } \\
\text { modules }\end{array}$ & $\begin{array}{l}\text { Recommendations for } \\
\text { upscaling gas separation } \\
\text { process on industrial } \\
\text { membrane modules }\end{array}$ & [23] \\
\hline Gas separation & $\begin{array}{c}\text { Design of technological } \\
\text { systems }\end{array}$ & $\begin{array}{c}\text { Consideration of variable } \\
\text { permeability, drop pressure } \\
\text { and/or non-isothermal } \\
\text { conditions. Multi-component, } \\
\text { multi-membrane, } \\
\text { multi-operation processes }\end{array}$ & $\begin{array}{c}\text { Possibilities for future } \\
\text { applications are discussed }\end{array}$ & {$[24]$} \\
\hline $\begin{array}{l}\text { Hydrogen/alkane } \\
\text { separation }\end{array}$ & $\begin{array}{l}\text { Olefins and paraffins } \\
\mathrm{C}_{2}-\mathrm{C}_{4} \text { extraction from } \\
\text { gas streams }\end{array}$ & $\begin{array}{l}\text { Effects of hollow } \\
\text { fiber module design and gas } \\
\text { flow mode }\end{array}$ & $\begin{array}{l}\text { Separation of } \mathrm{H}_{2} / \mathrm{CO}_{2}, \\
\mathrm{H}_{2} / \mathrm{C}_{2} \mathrm{H}_{6} \text { and } \mathrm{H}_{2} / \mathrm{C}_{3} \mathrm{H}_{8} \\
\text { gas mixtures }\end{array}$ & {$[25]$} \\
\hline $\begin{array}{l}\text { Vacuum sweep for the } \\
\text { dehumidification of air }\end{array}$ & $\begin{array}{l}\text { Control of water vapor } \\
\text { and air permeance; } \\
\text { heat and mass transfer }\end{array}$ & $\begin{array}{c}\text { Varying the geometry of } \\
\text { modules and schemes with } \\
\text { partial recycling }\end{array}$ & $\begin{array}{l}\text { Decrease in the resistance } \\
\text { of the membrane boundary } \\
\text { layer towards mass } \\
\text { transfer }\end{array}$ & [26] \\
\hline $\begin{array}{l}\text { Gas/liquid membrane } \\
\text { contactors }\end{array}$ & $\begin{array}{l}\text { Mass transfer in } \mathrm{HF} \\
\text { module }\end{array}$ & $\begin{array}{l}\text { (1) module design with } \\
\text { optimized flow geometry } \\
\text { (2) use of external energy }\end{array}$ & $\begin{array}{l}\text { Increase in the productivity } \\
\text { factor by } 3 \text { to } 15\end{array}$ & {$[27]$} \\
\hline
\end{tabular}


Table 1. Cont.

\begin{tabular}{|c|c|c|c|c|}
\hline $\begin{array}{c}\text { Purpose of the } \\
\text { Membrane Module }\end{array}$ & Improvement Area & Improvement Method & Remark & Ref. \\
\hline $\begin{array}{l}\text { Gas/liquid membrane } \\
\text { contactors }\end{array}$ & $\begin{array}{l}\text { Improving mass } \\
\text { transfer }\end{array}$ & $\begin{array}{l}\text { Development of a pulsation } \\
\text { module that imposes a } \\
\text { sinusoidally fluctuating bore } \\
\text { liquid flow rate }\end{array}$ & $\begin{array}{l}\text { New method of HF } \\
\text { spinning }\end{array}$ & {$[28]$} \\
\hline $\begin{array}{l}\text { HF membrane } \\
\text { contactors (HFMC) }\end{array}$ & $\begin{array}{c}\text { HFMC: module } \\
\text { fabrication, design and } \\
\text { operation, potential } \\
\text { applications }\end{array}$ & $\begin{array}{l}\text { Gas/liquid contacting; } \\
\text { liquid/liquid contacting; } \\
\text { supported liquid membrane; } \\
\text { supported gas membrane; } \\
\text { fluid/fluid contacting }\end{array}$ & $\begin{array}{l}\text { Special focus on membrane } \\
\text { distillation, } \\
\text { dehumidification } \\
\text { of air and gas absorption } \\
\text { and stripping }\end{array}$ & [29] \\
\hline Membrane oxygenators & $\begin{array}{l}\text { Improvement of } \\
\text { hemocompatibility }\end{array}$ & $\begin{array}{l}\text { HF membranes treated by } \\
\text { plasma }\end{array}$ & $\begin{array}{l}\text { Surface-modified } \\
\text { polymeric HF membranes }\end{array}$ & {$[30]$} \\
\hline $\begin{array}{l}\text { Liquid/liquid } \\
\text { membrane contactors }\end{array}$ & $\begin{array}{l}\text { Hydrodynamics and } \\
\text { mass transfer }\end{array}$ & $\begin{array}{l}\text { Design of internal HF packing } \\
\text { in the module and selection of } \\
\text { operating conditions }\end{array}$ & $\begin{array}{l}\text { (1) creating an even flow } \\
\text { within the module and (2) } \\
\text { improving mixing }\end{array}$ & {$[31,32]$} \\
\hline $\begin{array}{l}\text { Liquid/liquid } \\
\text { membrane contactors }\end{array}$ & $\begin{array}{l}\text { HFs with improved } \\
\text { homogeneous } \\
\text { distribution of fluid } \\
\text { inside the module }\end{array}$ & $\begin{array}{l}\text { Dry and wet phase inversion } \\
\text { method } \\
\text { using asymmetric coagulation } \\
\text { conditions }\end{array}$ & Helix wave HF & {$[33]$} \\
\hline Membrane distillation & $\begin{array}{l}\text { Improving the design } \\
\text { and mechanical } \\
\text { stability of the } \\
\text { membrane }\end{array}$ & $\begin{array}{l}\text { Design of lotus-root-like } \\
\text { multi-bore HF membrane }\end{array}$ & $\begin{array}{l}\text { Improving the mechanical } \\
\text { strength of the membranes }\end{array}$ & {$[34]$} \\
\hline Membrane distillation & $\begin{array}{l}\text { Improving the design } \\
\text { of the membrane } \\
\text { module }\end{array}$ & $\begin{array}{l}\text { Novel cylindrical cross-flow } \\
\text { HF membrane module for } \\
\text { direct contact membrane } \\
\text { distillation }\end{array}$ & $\begin{array}{l}\text { Good accordance with } \\
\text { model predictions }\end{array}$ & [35] \\
\hline $\begin{array}{l}\text { Power generation from } \\
\text { seawater, desalination } \\
\text { forward osmosis (FO) } \\
\text { and pressure-retarded } \\
\text { osmosis (PRO) }\end{array}$ & Energy efficiency & $\begin{array}{l}\text { New types of modules with } \\
\text { shorter lengths and larger } \\
\text { diameters }\end{array}$ & $\begin{array}{l}\text { Energy recovery increases } \\
\text { by } 10-15 \%\end{array}$ & {$[36]$} \\
\hline $\mathrm{FO}$ & $\begin{array}{l}\text { Recuperation factor } \\
\text { and energy } \\
\text { consumption of FO } \\
\text { processes }\end{array}$ & $\begin{array}{l}\text { Experimental and theoretical } \\
\text { study of an FO HF membrane } \\
\text { module with a cross-wound } \\
\text { configuration }\end{array}$ & $\begin{array}{l}\text { Particular attention is paid } \\
\text { to the frequency of the } \\
\text { transverse winding of the } \\
\text { HFs in the module }\end{array}$ & {$[37]$} \\
\hline Membrane filtration & Fouling & $\begin{array}{l}\text { Computational fluid dynamics } \\
\text { (CFD) simulations of } \\
\text { fiber-fiber interaction in a HF } \\
\text { membrane bundle }\end{array}$ & $\begin{array}{c}\text { Fouling can be lowered by } \\
\text { proper fiber distance and } \\
\text { position in the bundle }\end{array}$ & [38] \\
\hline $\begin{array}{c}\text { Membrane separation } \\
\text { processes }\end{array}$ & $\begin{array}{l}\text { Improvement of mass } \\
\text { transfer coefficients }\end{array}$ & $\begin{array}{l}\text { New baffled membrane } \\
\text { modules made with HF fabric }\end{array}$ & $\begin{array}{l}\text { The performance of such } \\
\text { modules is routinely better } \\
\text { than that in more } \\
\text { conventional designs }\end{array}$ & [39] \\
\hline
\end{tabular}

Table 1 shows that the design of HF membrane modules occupies one of the key positions in the development of efficient membrane processes for various purposes. Improvements are aimed at increasing the efficiency of gas separation, membrane oxygenation, gas/liquid and liquid/liquid membrane contactors, FO, membrane distillation and filtration, energy recovery during the desalination of seawater by FO and PRO and modeling membrane processes. In fact, the actual results of the fundamental research in chemical engineering have led to a wide range of practical applications. This work focuses on the development of new membrane modules based on 3D structured HFs obtained by reagent-free 
technologies [12]. In particular, 3D membrane structures based on PMP HFs are suggested to improve the characteristics of HF membrane modules by increasing mass transfer on the shell side due to the regular distribution of HFs and creation of flow mixing, and avoiding the problem of channeling. PMP HF 3D structures are realized by textile processes-in particular, triaxial braiding and tape weaving. For the triaxial braiding, the number of braiding threads and the braiding angle are varied. For the tape-woven fabrics, different weft densities and binding methods are used. This leads to the realization of different membrane module geometries, which opens up new possibilities for the improvement of membrane processes. The application of textile processing can be harmful to HFs. Damage of HFs' walls or their collapse will lead to the loss of their membrane properties. The aim of this work is to investigate the gas transfer and separation characteristics of the newly developed 3D membrane structures based on PMP HFs compared to the same standalone PMP HFs in order to check their integrity and ensure that the HFs do not collapse after weaving and braiding processing.

\section{Materials and Methods}

\subsection{Hollow Fiber Preparation}

PMP type MX002, obtained from Mitsui Chemicals, Inc. (Minato, Tokyo, Japan), was used to prepare non-porous HFs with dense walls. PMP HFs were produced by the melt spinning process with a four-capillary core-shell spinneret and supporting air in the core using a laboratory-scale plant from Fourné Polymertechnik GmbH (Alfter, Germany). The preparation details of the HFs are given in [12]. Air was introduced in order to prevent the fibers from collapsing after extrusion, when the melt strength beyond the capillaries is not yet strong enough. The spinning process setup and a sketch of the 4-hole spin plate are depicted in Figure 1. The internal diameter of the HFs was around 3 times larger than that of the industrial "Graviton" HFs. This can help to prevent the problem of vapors' capillary condensation and blocking of HFs. A cross-section of a PMP HF obtained is shown in Figure 2. The HF almost has a round geometry, with slight deviations and non-uniformity of wall thickness. The geometry of the HFs was characterized by measuring the external and internal diameters of several HF samples in two perpendicular directions and averaging their diameters and wall thickness values. The average external and internal diameters were found to be equal to 187 and $111 \mu \mathrm{m}$, respectively; the average wall thickness was found to be equal to $38 \mu \mathrm{m}$. The processing parameters used for the preparation of the PMP HFs are presented in Table 2. The $\mathrm{T}_{\mathrm{g}}$ of the obtained HFs was found to be $21^{\circ} \mathrm{C}$.
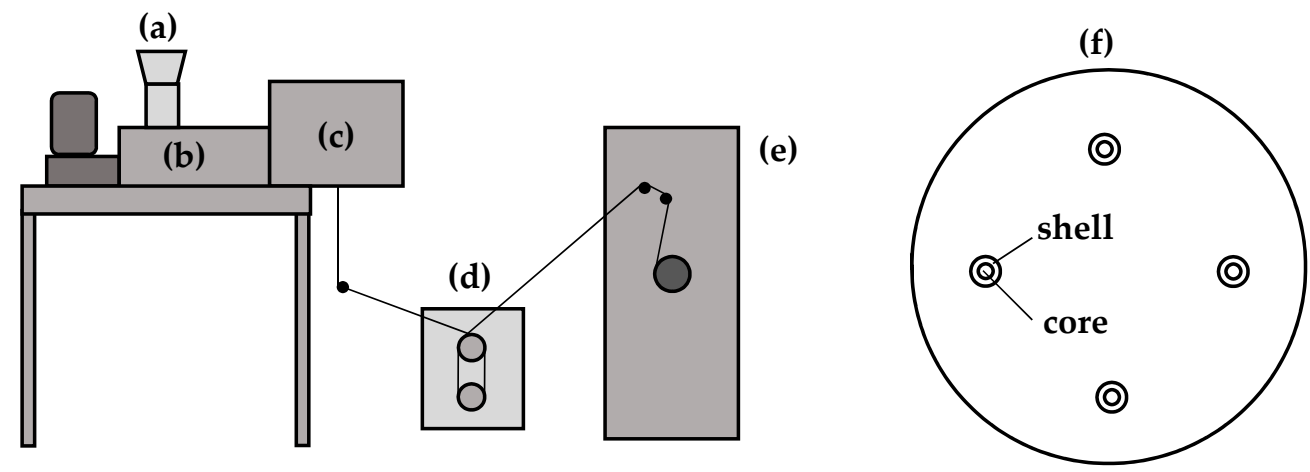

Figure 1. Laboratory-scale melt spinning setup and sketch of the 4-hole spin plate: (a) hopper; (b) extruder; (c) spin head; (d) godet duo; (e) winder; (f) 4-hole core-shell spin plate with supporting air in the core. 


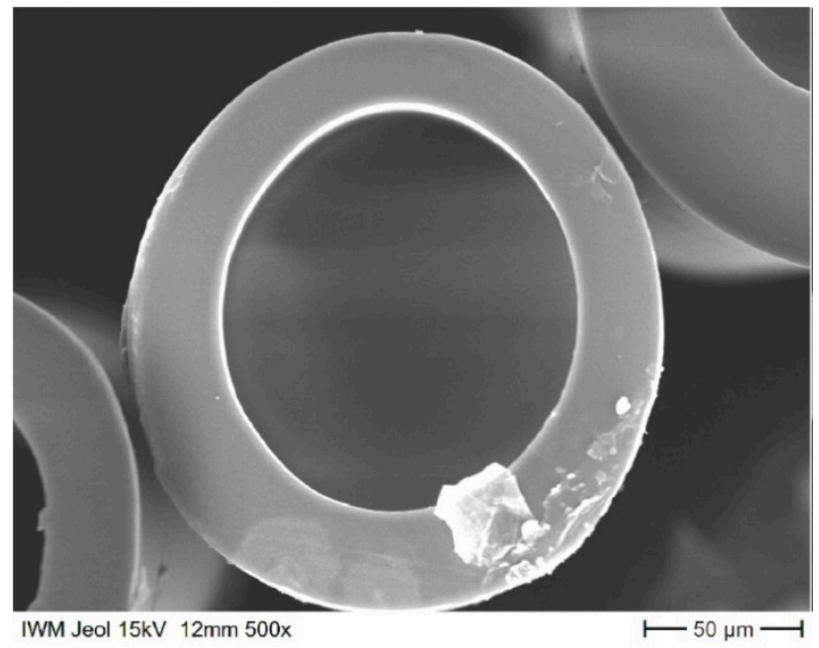

Figure 2. HF cross-sections.

Table 2. Setup and melt spinning parameters of the PMP HF preparation.

\begin{tabular}{ccccc}
\hline $\begin{array}{c}\text { Volumetric } \\
\text { Polymer Feed } \\
\left(\mathbf{c m}^{\mathbf{3}} / \text { Rotation) }\right.\end{array}$ & $\begin{array}{c}\text { Extruder } \\
\text { Rotation Speed } \\
\text { (Rotations/min) }\end{array}$ & $\begin{array}{c}\text { Spin Head } \\
\text { Temperature }\left({ }^{\circ} \mathbf{C}\right)\end{array}$ & $\begin{array}{c}\text { Specific Mass } \\
\text { Throughput } \\
\left(\mathbf{g ~ m m}^{-\mathbf{2}} \mathbf{h}^{-\mathbf{1}}\right)\end{array}$ & $\begin{array}{c}\text { Winding Speed } \\
(\mathbf{m} / \mathbf{m i n})\end{array}$ \\
\hline 0.16 & 13.13 & 280 & 103 & 25 \\
\hline
\end{tabular}

\subsection{D Braided and Woven Tape Fabrics}

At the Institut für Textiltechnik (ITA) of RWTH Aachen University, Germany, 3D structured fabrics were developed based on the HF described in Figure 3a,b. Different triaxial braided hoses were produced based on different braiding angles and numbers of standing threads. PMP monofilaments (not hollow) of the same fineness were used as braiding threads. Either 24 or 48 braiding threads were used in order to make the textile less or more dense, respectively. In each case, the number of standing threads parallel in the axial hose direction was 24 (each with four HFs). In Figure 3c, the tubular fabric with 48 braiding threads is depicted. In this work, braided HFs with a medium braiding angle $\left(45^{\circ}\right)$ were investigated.

The woven tape fabrics were produced using different bindings: twill binding and atlas binding. In the woven fabrics, $24 \mathrm{HF}$ threads (each with $4 \mathrm{HF}$ filaments) were used in the warp direction and monofilaments in the weft direction (Figure 4). The warp density was varied from $5 / \mathrm{cm}$ to $15 / \mathrm{cm}$. In fact, the preparation of $3 \mathrm{D}$ braided HF membrane structures can use the advantages of textile techniques, including variation of all parameters. Nevertheless, it is extremely important to keep HFs from collapsing, especially in the crossing points of warp and weft yarn. Moreover, special attention should be paid to gentle fiber handling when textile processing the HFs in order to prevent damage of the dense walls.

\subsection{Gas Permeability Measurements}

To measure the permeability of the 3D braided and tape-woven fabrics, laboratory membrane modules in metal design were created at the A.V. Topchiev Institute of Petrochemical Synthesis RAS (TIPS RAS), Moscow, Russia. The ends of the fabrics were placed into metal sleeves and encapsulated by a constructional adhesive based on epoxy resin (Figure $5 a, c)$. Protruding ends of HFs were cut when the adhesive was completely cured (Figure $5 b, d$ ) to ensure that all HF were opened. An overall view of the metal module is shown in Figure 5e. The working area of the HFs in the module was $70 \mathrm{~cm}^{2}$. 


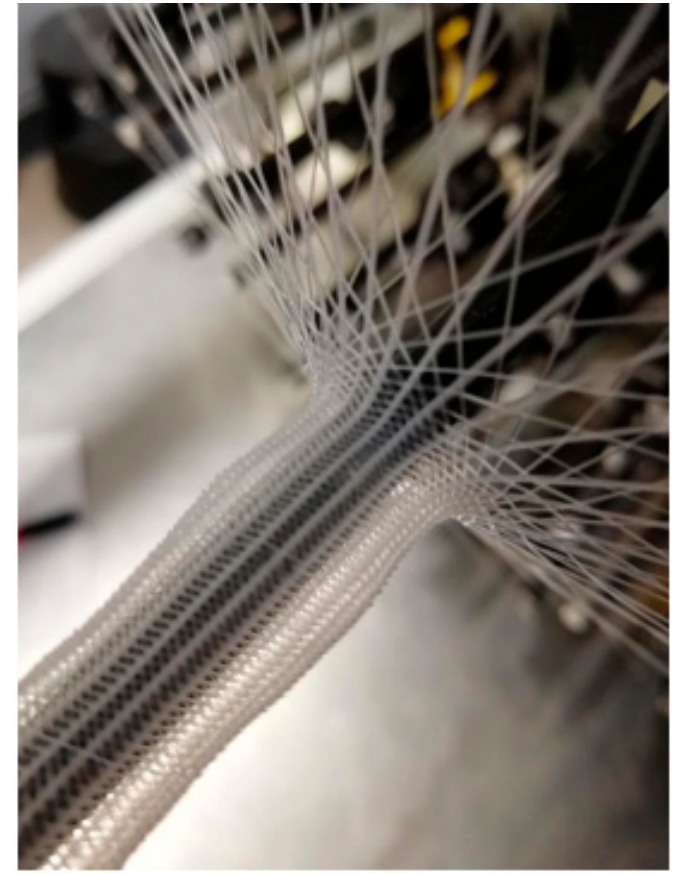

(a)

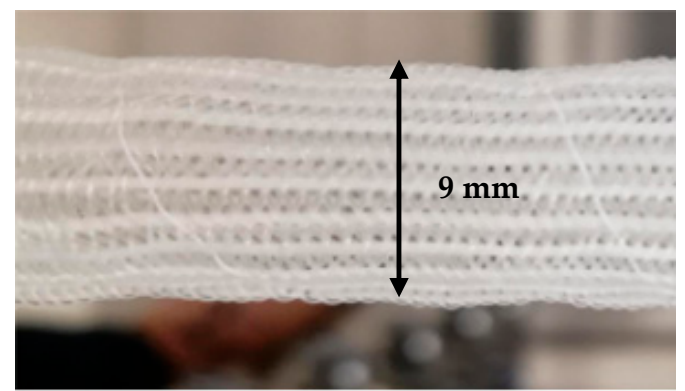

(b)

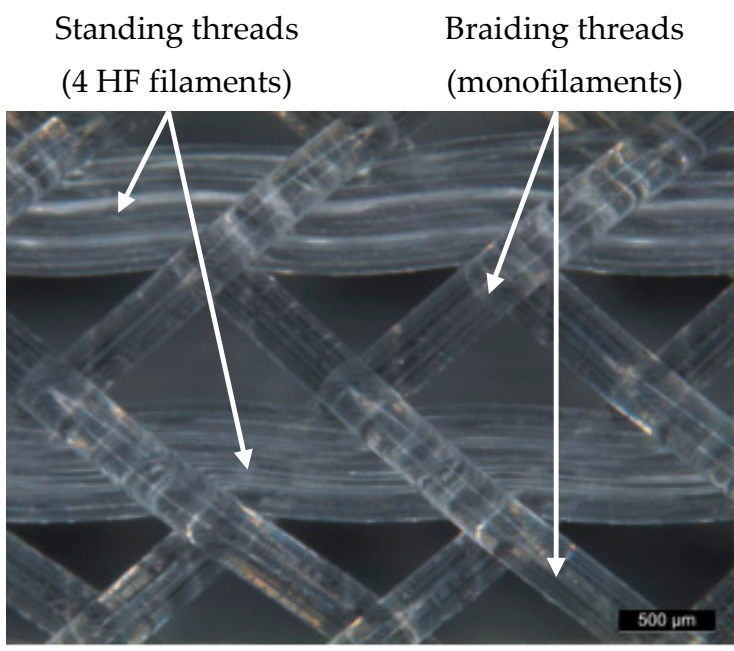

(c)

Figure 3. (a) Preparation of 3D structured HF fabrics via triaxial braiding; (b) braided hose; (c) structure of braided HF hose with medium braiding angle.

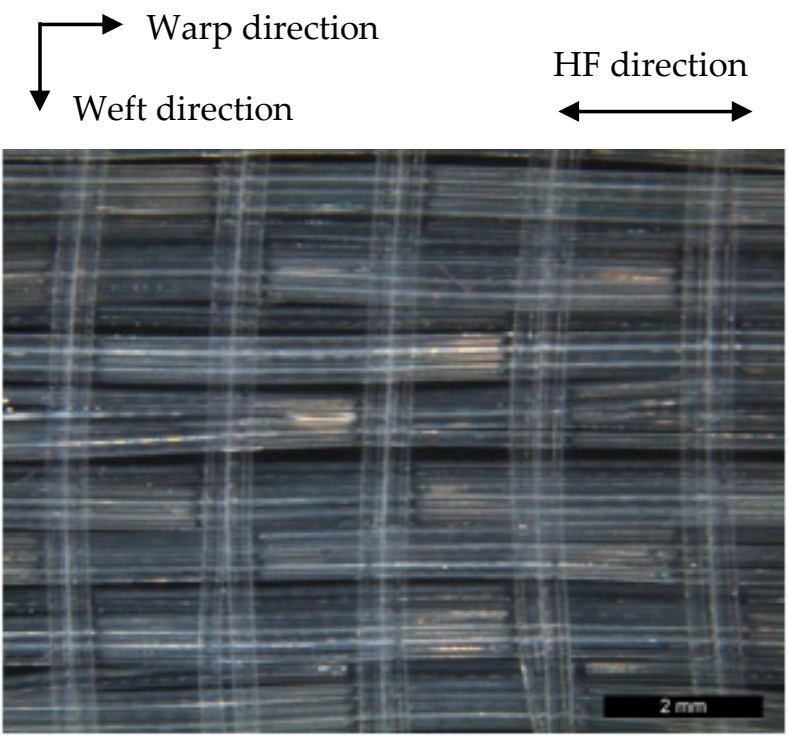

Figure 4. Woven HF fabric. 


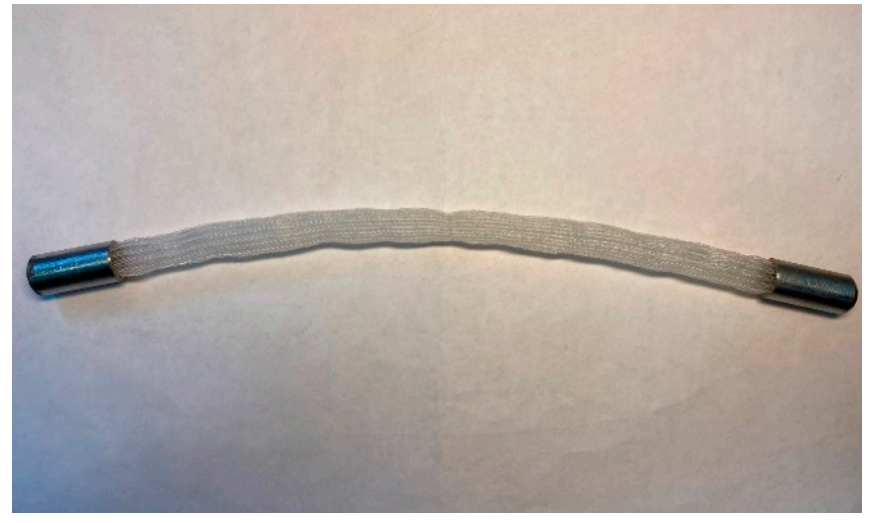

(a)

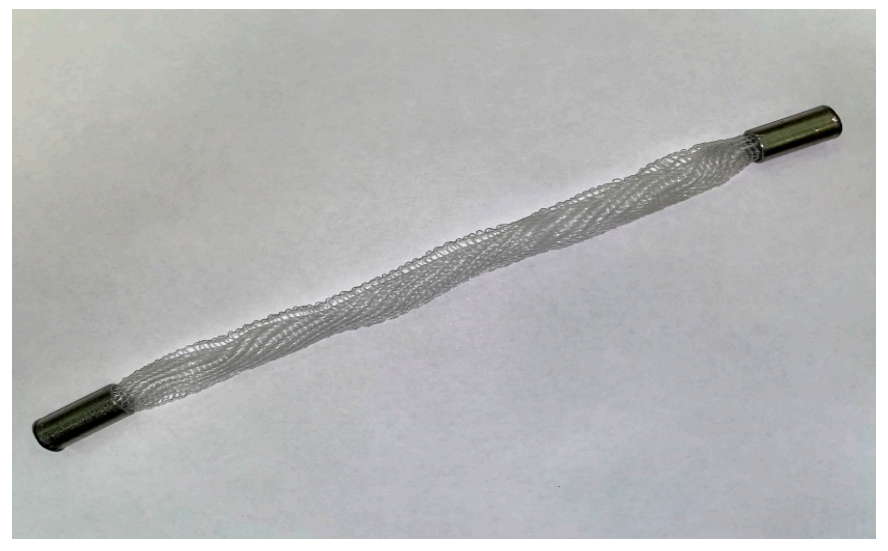

(c)

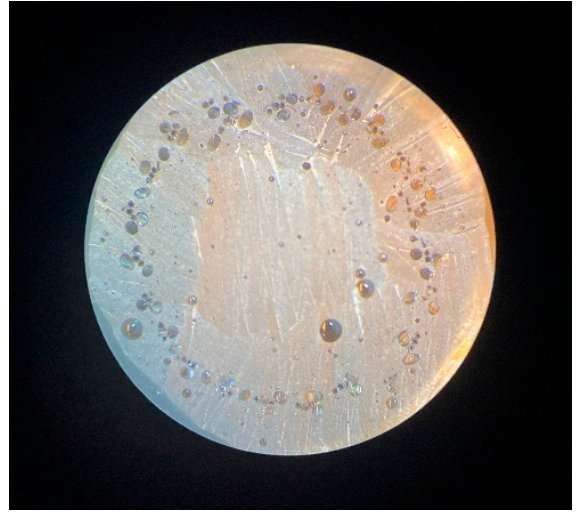

(b)

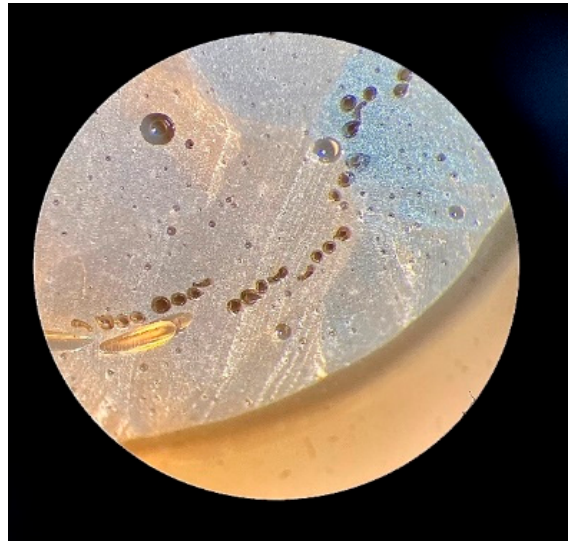

(d)

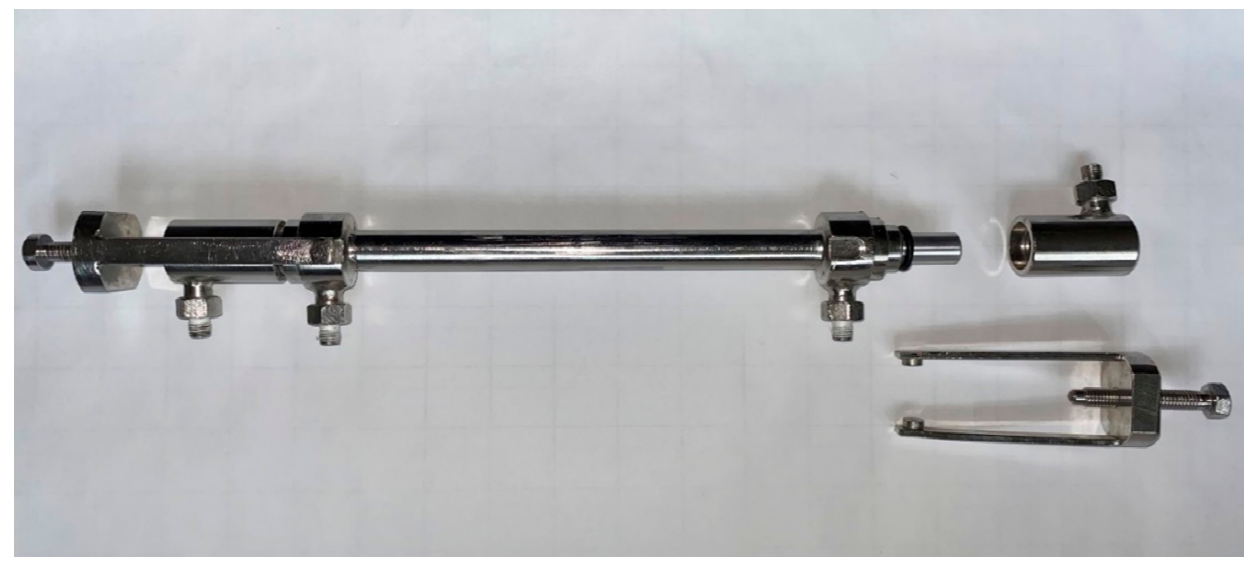

(e)

Figure 5. Lab-scale membrane module: (a) sealed 3D triaxial braided hose; (b) cross-section of the bore-side sealed entrance part; (c) sealed woven fabric (rolled); (d) cross-section of the bore-side sealed entrance part; (e) complete assembly of lab-scale membrane HF module.

In order to test the integrity of the HFs and to preserve their gas transport and separation characteristics after the formation of 3D structures, gas permeability was measured with a $\mathrm{CO}_{2} / \mathrm{CH}_{4}$ mixture (50/50 vol.\%), which was used previously to test initial PMP HFs [40].

The permeability measurements of laboratory membrane modules were carried out in the temperature range of 0 to $40{ }^{\circ} \mathrm{C}$ on a differential type set-up with gas chromatographic 
analysis. A detailed description of the experimental measurements of HFs can be found in [40].

The permeability coefficient through the HFs was calculated using the equation:

$$
P_{i}=\frac{J \cdot c_{i}^{\prime} \cdot L}{A \cdot p \cdot\left(c_{i}-c_{i}^{\prime}\right)},
$$

where $P$ is the permeability coefficient, Barrer $\left(7.5 \times 10^{-18}\left(\mathrm{~m}^{3} \cdot \mathrm{m}\right) /\left(\mathrm{s} \cdot \mathrm{m}^{2} \cdot \mathrm{Pa}\right)\right)$; $J$ is the flow rate of the gas carrier with the gas studied that exits from the bore side, $\mathrm{m}^{3}(\mathrm{STP}) / \mathrm{s} ; \mathrm{L}$ is the HF wall thickness, $\mathrm{m}$; $A$ is the working membrane area, $\mathrm{m}^{2} ; p$ is the atmospheric pressure, $\mathrm{Pa} ; c_{i}{ }^{\prime}$ is the concentration of the gas studied in the gas carrier stream from the bore side, vol. $\% ; c_{i}$ is the concentration of the gas studied in the shell side, vol. $\%$.

The selectivity of the gas pair was calculated as follows:

$$
\alpha_{i j}=\frac{P_{i}}{P_{j}}
$$

The following equation was used for the approximation of the temperature dependence of the permeability coefficient:

$$
P=P_{0} \exp \left(-\frac{E_{P}}{R T}\right)
$$

where $E_{p}$ is the apparent activation energy of permeability, $\mathrm{J} / \mathrm{mol}$; $T$ is the temperature, $\mathrm{K}$.

\section{Results}

Gas permeability coefficients for $\mathrm{CO}_{2}$ and $\mathrm{CH}_{4}$ obtained for triaxial braided hose and woven fabric with PMP HFs are presented in Table 3.

Table 3. Permeability coefficients of $3 \mathrm{D}$ structured $\mathrm{HFs}$ for $\mathrm{CO}_{2} / \mathrm{CH}_{4}$ mixture in the temperature range of 0 to $40^{\circ} \mathrm{C}$.

\begin{tabular}{ccccc}
\hline \multirow{2}{*}{$\mathbf{T},{ }^{\circ} \mathbf{C}$} & \multicolumn{2}{c}{ Permeability Coefficients $\boldsymbol{P}$, Barrer } & Selectivity of & Type \\
\cline { 2 - 3 } $\mathbf{C O}_{\mathbf{2}} / \mathbf{C H}_{\mathbf{4}}$ & \\
\hline-0.2 & $\mathbf{C O}_{\mathbf{2}}$ & 4.0 & 10.0 & Triaxial braided hose \\
0.6 & 40.0 & 4.5 & 9.2 & Tape-woven fabric \\
\hline 15.2 & 51.0 & 7.8 & 6.9 & Triaxial braided hose \\
15.3 & 54.1 & 7.8 & 6.9 & Tape-woven fabric \\
\hline 21.0 & 63.5 & 9.8 & 6.2 & Triaxial braided hose \\
23.5 & 65.2 & 10.8 & 6.0 & Tape-woven fabric \\
\hline 39.9 & 97.9 & 21.0 & 4.7 & Triaxial braided hose \\
39.8 & 95.9 & 20.7 & 4.6 & Tape-woven fabric \\
\hline
\end{tabular}

Table 4. Apparent activation energies of the gas permeability for different lab-scale membrane modules.

\begin{tabular}{cccc}
\hline \multirow{2}{*}{$\begin{array}{c}\text { Lab-Scale Membrane HF } \\
\text { Module }\end{array}$} & \multicolumn{2}{c}{ Apparent Activation Energy of Permeability, } & \multirow{2}{*}{ Reference } \\
\cline { 2 - 3 } & $\mathbf{C O}_{\mathbf{P}}, \mathbf{k J} / \mathbf{m o l}$ & $\mathbf{C H}_{\mathbf{4}}$ & \\
\cline { 2 - 3 } & 14.3 & 27.7 & {$[40]$} \\
Industrial “Graviton” HFs & 12.9 & 25.0 & {$[40]$} \\
Laboratory HFs & 15.8 & 29.3 & Present work \\
Triaxial braided hose & 15.5 & 27.7 & Present work \\
Tape-woven fabric & & & \\
\hline
\end{tabular}


Temperature dependences of permeability under an Arrhenius plot are shown in Figures 6 and 7. Calculated apparent activation energies are presented in Table 4.

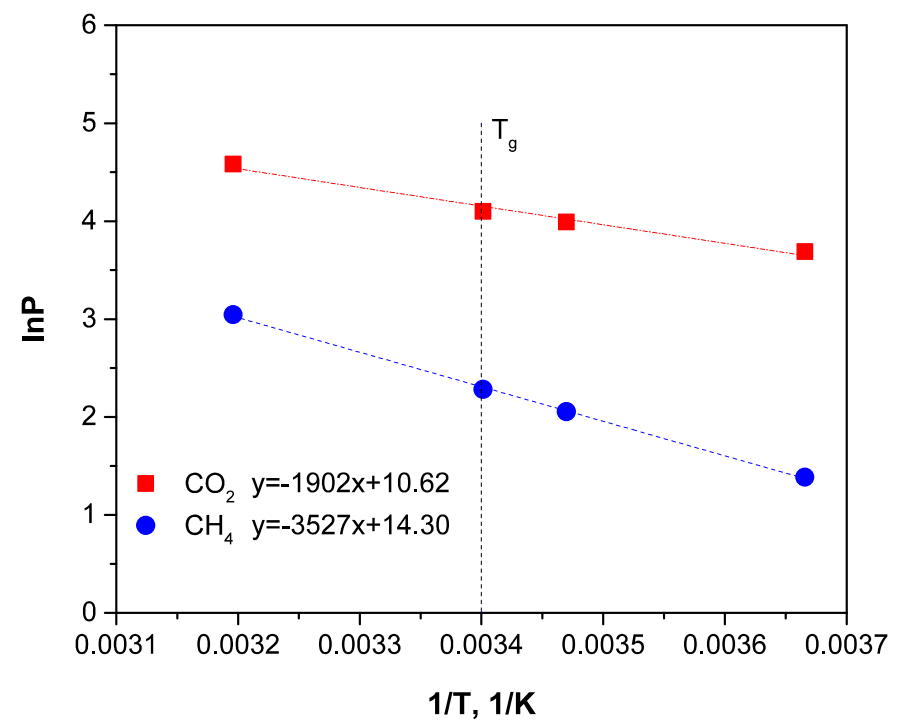

Figure 6. Temperature-dependent permeability coefficient of the triaxial braided hose membrane module for $\mathrm{CO}_{2}$ and $\mathrm{CH}_{4}$ in the mixture (50/50\%vol.).

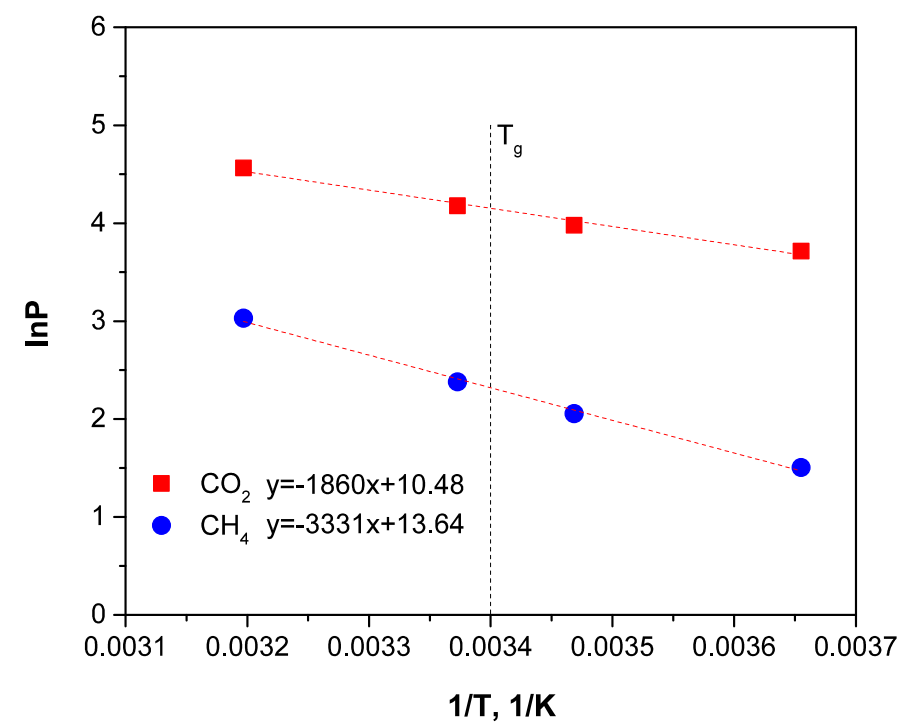

Figure 7. Temperature-dependent permeability coefficient of the tape-woven fabric membrane module for $\mathrm{CO}_{2}$ and $\mathrm{CH}_{4}$ in the mixture (50/50\%vol.).

\section{Discussion}

As can be seen from Table 3, the gas permeability coefficients of the different types of lab-scale membrane modules are similar to each other. Moreover, the results obtained were close to the properties of the same standalone fibers, which had permeability coefficients of 68.4 and 11.9 for $\mathrm{CO}_{2}$ and $\mathrm{CH}_{4}$, respectively, at $25^{\circ} \mathrm{C}$. These results show that the bores of HFs remained opened. At the same time, the level of $\mathrm{CO}_{2} / \mathrm{CH}_{4}$ selectivity indicates the absence of defects in the HF walls. Both observations allow us to conclude that the developed PMP HFs have sufficient mechanical properties to maintain their membrane characteristics during processing by applied textile methods.

Figures 6 and 7 demonstrate that the temperature dependences of permeability are typical linear dependences under an Arrhenius plot, and fracture near the polymer $\mathrm{T}_{\mathrm{g}}$ is 
absent. The $\mathrm{CO}_{2}$ and $\mathrm{CH}_{4}$ apparent activation energies of permeability in 3D structured HFs were found to be close to the data obtained earlier (Table 4).

The comparison of the $\mathrm{CO}_{2}$ permeability coefficient and $\mathrm{CO}_{2} / \mathrm{CH}_{4}$ selectivity values obtained in this work with data reported in [41] at $35^{\circ} \mathrm{C}$ demonstrates good agreement. However, the value of $\mathrm{CO}_{2} / \mathrm{CH}_{4}$ selectivity reported in [13] is 8.6, which is noticeably higher compared to the value of 5.4 reported in [41] and 5.0 obtained in this work (by interpolation of experimental data for the temperature of $35^{\circ} \mathrm{C}$ ). Figure 8 shows the comparison as a Robeson plot for the $\mathrm{CO}_{2} / \mathrm{CH}_{4}$ pair, including the values at different temperatures in the studied range $0-40^{\circ} \mathrm{C}$; a decrease in temperature leads to a decrease in $\mathrm{CO}_{2}$ permeability in PMP and a rise in $\mathrm{CO}_{2} / \mathrm{CH}_{4}$ selectivity. PMP filling with nanoparticles and the creation of mixed matrix membranes $(\mathrm{MMM}) \mathrm{s}$ can improve the $\mathrm{CO}_{2}$ permeability and $\mathrm{CO}_{2} / \mathrm{CH}_{4}$ selectivity, which was demonstrated in [16,42]. These data added in Figure 8 show that PMP-based MMMs can potentially reach the selectivity level of commercial polymers, which are used for the production of gas separation membranes: polyimides (Matrimid ${ }^{\circledR \circledR}$ and Kapton ${ }^{\circledR \circledR}$ ) [43,44], cellulose acetate and polysulfone [45]. However, the influence of such PMP modification on the HF melt spinning process has to be studied, and the change in the HFs' mechanical properties has to be taken into account in order to withstand further braiding or weaving.

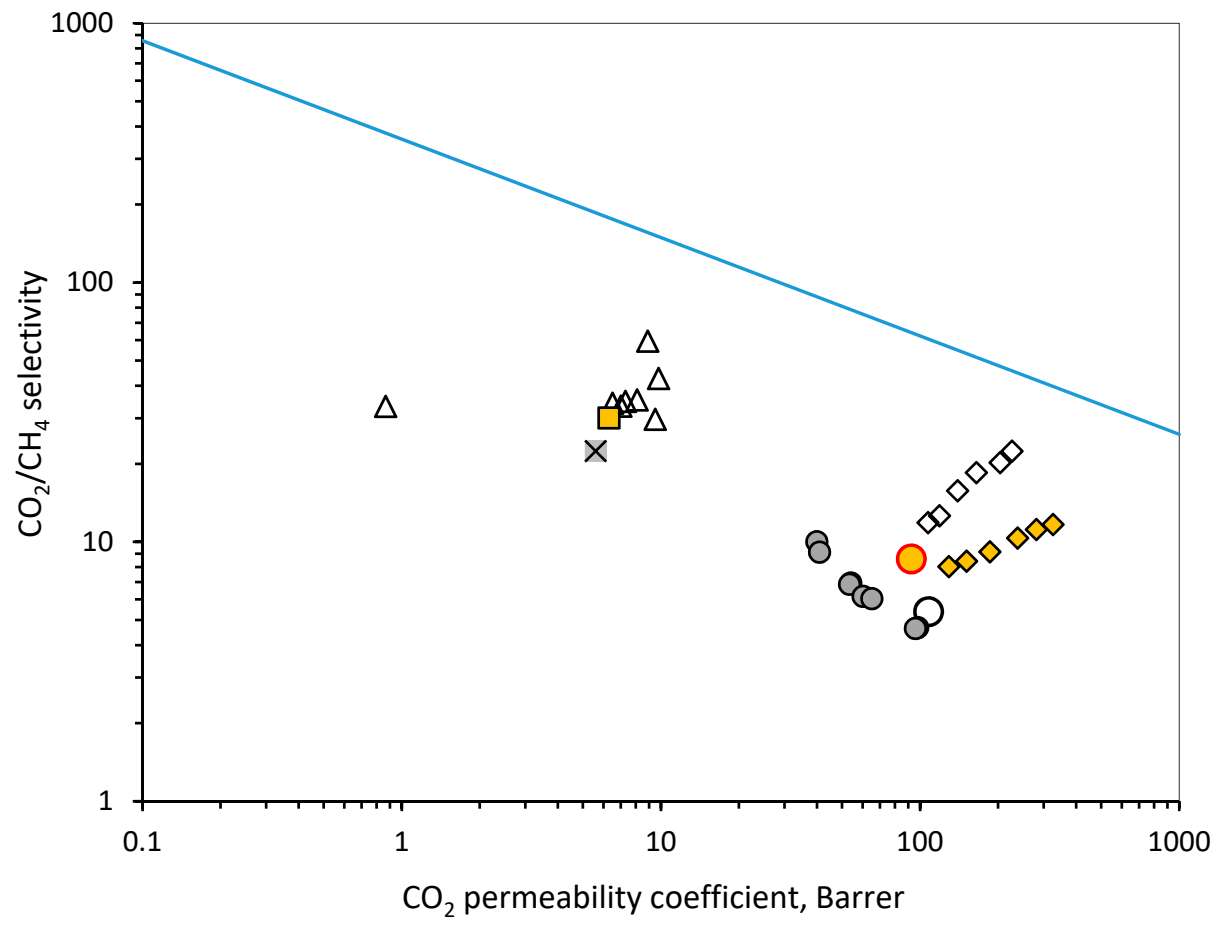

Figure 8. Robeson plot for $\mathrm{CO}_{2} / \mathrm{CH}_{4}$ pair: - 2008 Upperbound; O PMP [13]; O PMP [41]; O PMP this work $\left(0-40^{\circ} \mathrm{C}\right) ; \diamond$ PMP MMMs with MIL53 [42]; $\diamond$ PMP MMMs with Al2O3 [16]; $\Delta$ Commercial polyimides [43,44]; $\square$ Cellulose acetate [45]; $\times$ Polysulfone [45].

Results show that new membrane modules can be obtained from melt-spun PMP HFs using textile processing methods. The most suitable method can be selected depending on the required module geometry and desired hydrodynamic conditions. In the case of HFs with both weaving and braiding, a uniform distribution of fibers without collapse is ensured. The problem of channeling in the shell side, typical of HF membrane modules, can be avoided using modules based on braided structures.

New configurations of membrane modules have the potential to be used not only for typical membrane gas separation systems, but also as gas/liquid membrane contactors for applications in medicine, biology, the creation of protective tissues, contactors and pertractors for various purposes. The development of 3D braided HF modules has the 
potential to stimulate the creation of membrane systems for new and unusual practical applications. Membranes based on PMP can be applied in gas separation processes, where membranes based on other polymers are not stable. They can be used to separate hydrocarbons [40] or gas mixtures with VOC vapors. Moreover, PMP HFs can be used to create membrane contactors for processes with chemically aggressive absorbents. The potential of HF weaving and braiding using textile techniques is the creation of regular structures that can significantly improve the mass exchange conditions in the shell side of HF membrane modules due to the flow mixing and avoidance of channeling [46].

\section{Conclusions}

The paper presents new approaches for designing HF membrane modules using the form of 3D membrane structures. PMP seems to be practically the only polymer that makes it possible to obtain HFs and 3D braided membrane modules in the form of hoses and fabrics, using the solvent-free "green route". The proposed textile technique retains the gas transport and separation properties of PMP-based HFs. Taking into account the high chemical resistance of PMP and its stability towards volatile organic compounds, new membrane processes can be developed for separating complex gaseous media (including toxic and reactive components) and creating membrane contactors for application with aggressive absorbents.

Author Contributions: Conceptualization, V.V.T. and T.G.; investigation, A.V.D., S.Y.M., M.P. and T.V.; writing-original draft preparation, S.Y.M.; writing-review and editing, M.P., M.G.S. and V.V.T.; supervision, M.P. and M.G.S. All authors have read and agreed to the published version of the manuscript.

Funding: This research was funded by the RUSSIAN SCIENCE FOUNDATION, grant number 19-49-04105, and DEUTSCHE FORSCHUNGSGEMEINSCHAFT, grant number GR1311/94-1.

Institutional Review Board Statement: Not applicable.

Informed Consent Statement: Not applicable.

Acknowledgments: The equipment of the TIPS RAS Center of collective use "New petrochemical processes, polymeric composites and adhesives" was used for the gas permeation measurements.

Conflicts of Interest: The authors declare no conflict of interest. The funders had no role in the design of the study; in the collection, analyses, or interpretation of data; in the writing of the manuscript, or in the decision to publish the results.

\section{References}

1. Khulbe, K.C.; Feng, C.; Matsuura, T.; Khayet, M. Polymeric Hollow Fibers: State of the Art Review of Their Preparation, Characterization and Applications in Different Research Areas. J. Appl. Membr. Sci. Technol. 2006, 4, 53-88. [CrossRef]

2. Crank, J.; Park, G. Diffusion in Polymers; Academic Press: London, UK; New York, NY, USA, 1969.

3. Paul, D.R.; Yampol'skii, Y.P. Polymeric Gas Separation Membranes; CRC Press, Inc.: Boca Raton, FL, USA, 1994.

4. Mulder, M. Basic Principles of Membrane Technology; Kluwer Academic Publishers: Dordrecht, The Netherlands, 1999.

5. Baker, R.W. Membrane Technology and Applications, 2nd ed.; John Wiley \& Sons Ltd: Chichester, UK, 2004.

6. Beckman, I.N.; Shalygin, M.G.; Teplyakov, V.V. Particularities of membrane gas separation under unsteady state conditions. In Mass Transfer in Chemical Engineering Processes; Markoš, J., Ed.; InTech: Rijeka, Croatia, 2011; pp. 205-232.

7. Henis, J.M.S.; Tripodi, M.K. A novel approach to gas separations using composite hollow fiber membrabnes. Sep. Sci. Technol. 1980, 15, 1059-1068. [CrossRef]

8. Wen, X.; Tresco, P.A. Fabrication and characterization of permeable degradable poly(DL-lactide-co-glycolide) (PLGA) hollow fiber phase inversion membranes for use as nerve tract guidance channels. Biomaterials 2006, 27, 3800-3809. [CrossRef]

9. Ashtiani, S.; Khoshnamvand, M.; Cihal, P.; Dendisova, M.; Randova, A.; Bousa, D.; Shaliutina-Kolesova, A.; Sofer, Z.; Friess, K. Fabrication of a PVDF membrane with tailored morphology and properties via exploring and computing its ternary phase diagram for wastewater treatment and gas separation applications. RSC Adv. 2020, 10, 40373. [CrossRef]

10. Ashtiani, S.; Khoshnamvand, M.; Regmi, C.; Friess, K. Interfacial Design of Mixed Matrix Membranes via Grafting PVA on UiO-66- $\mathrm{NH}_{2}$ to Enhance the Gas Separation Performance. Membranes 2021, 11, 419. [CrossRef] [PubMed]

11. Huang, Y.; Xiao, C.; Huang, Q.; Liu, H.; Zhao, J. Progress on polymeric hollow fiber membrane preparation technique from the perspective of green and sustainable development. Chem. Eng. J. 2021, 403, 126295. [CrossRef] 
12. Pelzer, M.; Vad, T.; Becker, A.; Gries, T.; Markova, S.; Teplyakov, V. Melt Spinning and Characterization of Hollow Fibres from Poly(4-methyl-1-pentene). J. Appl. Polym. Sci. 2020, 138, e49630. [CrossRef]

13. Lopez, L.C. Synthesis, structure and properties of poly(4-methyl-1-pentene). J. Macromol. Sci. Part C 1992, 32, 301-406. [CrossRef]

14. Mitsui Chemicals. TPX Properties. Available online: https://jp.mitsuichemicals.com/en/special/tpx/properties/ (accessed on 15 December 2021).

15. Zhang, G.; Baer, E.; Hiltner, A. Gas permeability of poly(4-methylpentene-1) in a confined nanolayered film system. Polymer 2013, 54, 4298-4308. [CrossRef]

16. Nematollahi, M.H.; Dehaghani, A.H.S.; Abedini, R. $\mathrm{CO}_{2} / \mathrm{CH}_{4}$ separation with poly(4-methyl-1-pentyne) (TPX) based mixed matrix membrane filled with $\mathrm{Al}_{2} \mathrm{O}_{3}$ nanoparticles. Korean J. Chem. Eng. 2016, 33, 657-665. [CrossRef]

17. Dehaghani, A.H.S.; Pirouzfar, V.; Alihosseini, A. Novel nanocomposite membranes-derived poly(4-methyl-1-pentene)/functionalized titanium dioxide to improve the gases transport properties and separation performance. Polym. Bull. 2020, 77, 6467-6489. [CrossRef]

18. Shafie, Z.M.H.M.; Ahmad, A.L.; Rode, S.; Belaissaoui, B.; Roizard, D.; Low, S.C. Prospect of Oxyplus Hollow Fibre Membrane with Dense Polymethylpentene (PMP) Skin as Support-gutter Layer of Thin Film Composite (TFC) for Biogas Upgrading. J. Phys. Sci. 2019, 30, 179-189. [CrossRef]

19. Kostrov, Y.A.; Mostovaya, G.B.; Ignatenko, T.I.; Ardashnikov, A.Y.; Khutorskii, B.Y. Graviton hollow gas-separating fibre. Fibre Chem. 1987, 18, 479-481. [CrossRef]

20. Evseev, A.K.; Zhuravel, S.V.; Alentiev, A.Y.; Goroncharovskaya, I.V.; Petrikov, S.S. Membranes in Extracorporeal Blood Oxygenation Technology. Membr. Membr. Technol. 2019, 1, 201-211. [CrossRef]

21. LivaNova. EOS ECMO. Available online: https://www.livanova.com/en-GB/Home/Products-Therapies/Cardiovascular/ Healthcare-Professionals/Advanced-Circulatory-Support/ExtraCorporeal-Life-Support/Eos-ECMO.aspx (accessed on 25 October 2021).

22. Xenios Campus. Available online: https://www.xenios-campus.com/tutorial/trailer_whitepaper_ecmo_in_covid-19_disease/ (accessed on 25 October 2021).

23. Li, D.; Wang, R.; Chung, T.-S. Fabrication of lab-scale hollow fiber membrane modules with high packing density. Sep. Purif. Technol. 2004, 40, 15-30. [CrossRef]

24. Wey, M.-Y.; Chen, H.-H.; Lin, Y.-T.; Tseng, H.-H. Thin carbon hollow fiber membrane with Knudsen diffusion for hydrogen/alkane separation: Effects of hollow fiber module design and gas flow mode. Int. J. Hydrog. Energy 2020, 45, 7290-7302. [CrossRef]

25. Scovazzo, P.; MacNeill, R. Membrane module design, construction, and testing for vacuum sweep dehumidification (VSD): Part I, prototype development and module design. J. Membr. Sci. 2019, 576, 96-107. [CrossRef]

26. Yang, X.; Wang, R.; Fane, A.G.; Tang, C.Y.; Wenten, I.G. Membrane module design and dynamic shear-induced techniques to enhance liquid separation by hollow fiber modules: A review. Desalination Water Treat. 2013, 51, 3604-3627. [CrossRef]

27. Luelf, T.; Tepper, M.; Breisig, H.; Wessling, M. Sinusoidal shaped hollow fibers for enhanced mass transfer. J. Membr. Sci. 2017, 533, 302-308. [CrossRef]

28. Pabby, A.K.; Wickramasinghe, S.R.; Sirkar, K.K.; Sastre, A.-M. Hollow Fiber Membrane Contactors: Module Fabrication, Design and Operation, and Potential Applications; CRC Press: Boca Raton, FL, USA, 2020.

29. Huang, X.; Wang, W.; Zheng, Z.; Fan, W.; Mao, C.; Shi, J.; Li, L. Surface monofunctionalized polymethyl pentene hollow fiber membranes by plasma treatment and hemocompatibility modification for membrane oxygenators. Appl. Surf. Sci. 2016, 362, 355-363. [CrossRef]

30. Wan, C.F.; Yang, T.; Lipscomb, G.G.; Stookey, D.J.; Chung, T.-S. Design and fabrication of hollow fiber membrane modules. In Hollow Fiber Membranes Fabrication and Applications; Chung, T.-S., Feng, Y., Eds.; Elsevier: Amsterdam, The Netherlands, 2021; pp. 225-252.

31. Ghogomu, J.; Guigui, C.; Rouch, J.; Clifton, M.; Aptel, P. Hollow-fibre membrane module design: Comparison of different curved geometries with Dean vortices. J. Membr. Sci. 2001, 181, 71-80. [CrossRef]

32. Park, S.R.; Kim, J.-H.; Ali, A.; Macedonio, F.; Drioli, E. A novel approach to synthesize helix wave hollow fiber membranes for separation applications. J. Membr. Sep. Technol. 2015, 4, 8-14.

33. Wang, P.; Chung, T.-S. Design and fabrication of lotus-root-like multi-bore hollow fiber membrane for direct contact membrane distillation. J. Membr. Sci. 2012, 421-422, 361-374. [CrossRef]

34. Singh, D.; Li, L.; Obusckovic, G.; Chau, J.; Sirkar, K.K. Novel cylindrical cross-flow hollow fiber membrane module for direct contact membrane distillation-based desalination. J. Membr. Sci. 2018, 545, 312-322. [CrossRef]

35. Tanaka, Y.; Yasukawa, M.; Goda, S.; Sakurai, H.; Shibuya, M.; Takahashi, T.; Matsuyama, H. Experimental and simulation studies of two types of 5-inch scale hollow fiber membrane modules for pressure-retarded osmosis. Desalination 2018, 447, 133-146. [CrossRef]

36. Shibuya, M.; Yasukawa, M.; Goda, S.; Sakurai, H.; Takahashi, T.; Higa, M.; Matsuyama, H. Experimental and theoretical study of a forward osmosis hollow fiber membrane module with a cross-wound configuration. J. Membr. Sci. 2016, 504, 10-19. [CrossRef]

37. Ma, C.; Liu, Y.; Li, F.; Shen, C.; Huang, M.; Wang, Z.; Sand, W. CFD simulations of fiber-fiber interaction in a hollow fiber membrane bundle: Fiber distance and position matters. Sep. Purif. Technol. 2019, 209, 707-713. [CrossRef]

38. Wang, K.L.; Cussler, E.L. Baffled membrane modules made with hollow fiber fabric. J. Membr. Sci. 1993, 85, 265-278. [CrossRef] 
39. Castel, C.; Bounaceur, R.; Favre, E. Engineering of membrane gas separation processes: State of the art and prospects. J. Membr. Sci. Res. 2020, 6, 295-303.

40. Markova, S.Y.; Pelzer, M.; Shalygin, M.G.; Vad, T.; Gries, T.; Teplyakov, V.V. Gas separating hollow fibres from poly(4-methyl-1pentene): A new development. Sep. Purif. Technol. 2022, 278, 119534. [CrossRef]

41. Mohr, J.M.; Paul, D.R.; Taru, Y. Surface fluorination of composite membranes. Part II. Characterization of the fluorinated layer. J. Memb. Sci. 1991, 55, 149-171. [CrossRef]

42. Abedini, R.; Omidkhah, M.; Dorosti, F. Highly permeable poly (4-methyl-1-pentene)/ $\mathrm{NH}_{2}$-MIL 53 (Al) mixed matrix membrane for $\mathrm{CO}_{2} / \mathrm{CH}_{4}$ separation. RSC Adv. 2014, 4, 36522-36537. [CrossRef]

43. Chen, X.Y.; Vinh-Thang, H.; Ramirez, A.A.; Rodrigue, D.; Kaliaguine, S. Membrane gas separation technologies for biogas upgrading. RSC Adv. 2015, 5, 24399-24448. [CrossRef]

44. Fernández-Castro, P.; Ortiz, A.; Gorri, D. Exploring the Potential Application of Matrimid®and ZIFs-Based Membranes for Hydrogen Recovery: A Review. Polymers 2021, 13, 1292. [CrossRef] [PubMed]

45. Vrbová, V.; Ciahotný, K. Upgrading Biogas to Biomethane Using Membrane Separation. Energy Fuels 2017, $31,9393-9401$. [CrossRef]

46. Bao, L.; Lipscomb, G.G. Mass transfer in axial flows through randomly packed fiber bundles. In Membrane Science and Technology; Bhattacharyya, D., Butterfield, D.A., Eds.; Elsevier: Amsterdam, The Netherlands, 2003; pp. 5-26. 